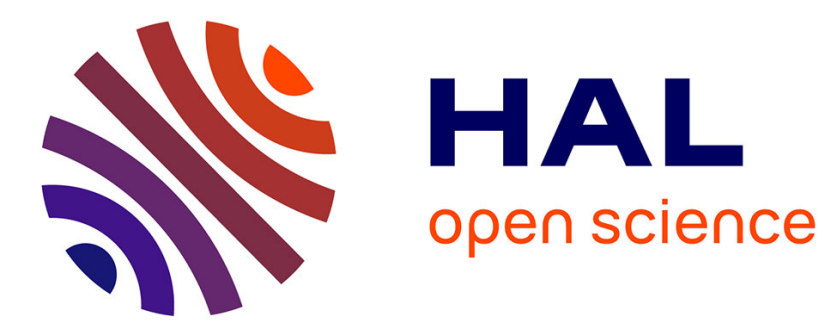

\title{
Low friction MoS2TiW Coatings Manufactured on X38CrMoV5-1 Steel Using PVD Method
}

Marcin Golabczak, Philippe Jacquet, Corinne Nouveau, Romain Fliti

\section{To cite this version:}

Marcin Golabczak, Philippe Jacquet, Corinne Nouveau, Romain Fliti. Low friction MoS2TiW Coatings Manufactured on X38CrMoV5-1 Steel Using PVD Method. Materials Science and Engineering Technology / Materialwissenschaft und Werkstofftechnik, 2013, 44 (5), pp.395-402. 10.1002/mawe.201300142 . hal-02544639

\section{HAL Id: hal-02544639 \\ https://hal.science/hal-02544639}

Submitted on 16 Apr 2020

HAL is a multi-disciplinary open access archive for the deposit and dissemination of scientific research documents, whether they are published or not. The documents may come from teaching and research institutions in France or abroad, or from public or private research centers.
L'archive ouverte pluridisciplinaire HAL, est destinée au dépôt et à la diffusion de documents scientifiques de niveau recherche, publiés ou non, émanant des établissements d'enseignement et de recherche français ou étrangers, des laboratoires publics ou privés. 


\title{
Low friction $\mathrm{MoS}_{2} \mathrm{TiW}$ coatings manufactured on X38CrMoV5-1 steel using PVD method
}

\section{Abriebarme $\mathrm{MoS}_{2}$ TiW Beschichtungen aufX38CrMoV5-1 Stahl mittels PVD-Verfahren}

\author{
M. Golabczak ${ }^{1}$, P. Jacquet ${ }^{2}$, C. Nouveau³ ${ }^{3}$ R. Fliti ${ }^{3}$
}

In this article the friction coefficients and the wear resistances of $\mathrm{MoS}_{2} \mathrm{TiW}$ protective coatings manufactured on X38CrMoV5-1 steel samples by using PVD technology are studied. The investigations based on tribometer tests which were carried out in different temperature conditions. The process of deposition of PVD coatings was realized by using multisource, hybrid factoryscale equipment of type URM 079. This equipment allows for deposition of coatings by the physical method. The tribological tests were performed using a precision high temperature tribometer under ambient and high temperature conditions with a steel and corundum balls as counter-samples. In this paper the results of these tribological tests are presented. It is shown that the measured friction coefficient of steel samples with PVD coatings is significantly lower than the friction coefficient of uncoated steel. It is also shown that X38CrMoV5-1 steel samples with manufactured $\mathrm{MOS}_{2} \mathrm{TiW}$ coatings are characterized by very low friction coefficient and high wear resistance.

Keywords: PVD method / Cathodic Arc Evaporation / $\mathrm{MoS}_{2}$ TiW coatings / Tribological investigations / Pinon-disc test / Wear resistance

In dieser Arbeit werden die Reibungskoeffizienten und die Abriebsbeständigkeit von $\operatorname{MoS}_{2} \mathrm{TiW}$ Schutzbeschichtungen, die auf X38CrMoV5-1 Stahlproben mittels des PVD-Verfahrens aufgebracht wurden, untersucht. Die Untersuchungen mittels Tribometer wurden bei unterschiedlichen Temperaturen durchgeführt. Der Abscheidungsprozess des PVD-Verfahrens wurde mittels einer hybriden kommerziellen Maschine des Typs URM 079 realisiert. Diese Anlage erlaubt das physikalische Aufbringen von Beschichtungen. Die tribologischen Tests wurden mittels eines Präzisions-Hochtemperaturtribometers bei Raumtemperatur und erhöhten Temperaturen mit Stahl- und Korundkugeln als Gegenkörper durchgeführt. Im Rahmen dieser Veröffentlichung werden die Ergebnisse der tribologischen Tests dargestellt. Es wird gezeigt, dass der gemessene Reibkoeffizient von Stahlproben mit PVD-Beschichtung signifikant geringer ist als der Reibkoeffizient von unbeschichtetem Stahl. Weiterhin wird gezeigt, dass sich X38CrMoV5-1 Stahlproben mit Mo$\mathrm{S}_{2}$ TiW Beschichtung durch einen sehr geringen Reibungskoeffizienten und hohe Verschleißbeständigkeit auszeichnen.

Schlüsselwörter: PVD-Verfahren / Kathodenstrahlzerstäubung / $\mathrm{MoS}_{2}$ TiW Beschichtung / tribologische Untersuchung / Stift-Scheibe-Tribometer / Verschleißbeständigkeit

\section{Introduction}

X38CrMoV5-1 steel (ASTM designation) is a very common hot working steel characterized by very good mechanical properties (high tensile strength, hardness, high abrasion resistance, high

\footnotetext{
${ }^{1}$ Technical University of Lodz, Department of Producton Engineering, Lodz, Poland

2 École Catholique Arts et Métiers-ECAM, Lyon, France

${ }^{3}$ Centre Arts et Métiers, Cluny, France

Corresponding author: M. Golabczak, Technical University of Lodz, Department of Production Engineering, Stefanowskiego 1/15, 90-924 Lodz, Poland

E-mail: marcin.golabczak@p.lodz.pl
}

yield stress - $2200 \mathrm{MPa}$ ). For this reason X38CrMoV5-1 steel is widely applied in various branches of industry e.g. in die casting and plastic forming [1]. Moreover, its abrasive wear resistance and hardness (especially in the surface layer) can be significantly improved through thermochemical treatments or by application of surface coatings (nitriding, CVD and PVD coatings) as well as by laser alloying of the surface with tungsten carbide [2]. Steel producers try to outdo one another in developing specialized grades of steel and treatments for them. In this paper the technology of manufacturing of $\mathrm{MoS}_{2} \mathrm{TiW}$ protective coatings on X38CrMoV5-1 steel using the plasma activated physical vapour deposition (PAPVD) method [3-5] is proposed. Moreover, the tribological investigation concerning measurement of friction coefficient and wear resistance of manufactured coatings is pre- 


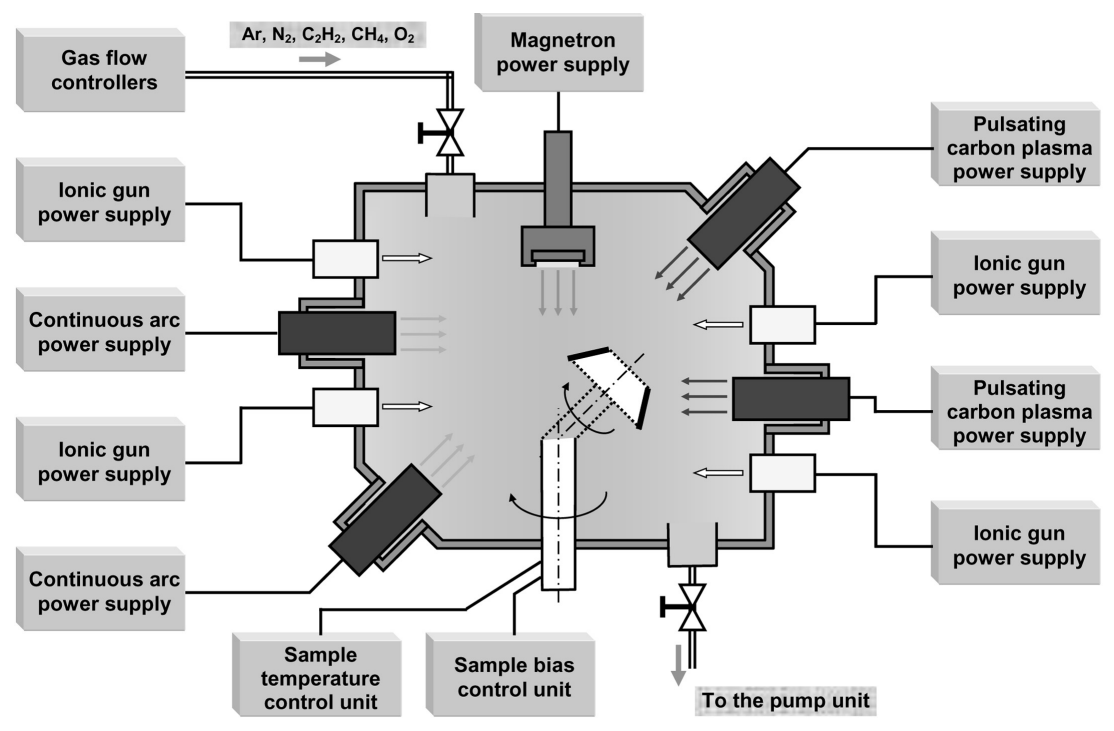

Figure 1. Scheme of arrangement of separate parts in the vacuum chamber of PVD Cathodic Arc Evaporation stand used for deposition of MoS $_{2}$. TiW coatings.

Bild 1. Schematische Darstellung der Anordnung der verschiedenen Teile in der Vakuum-Kammer einer PVD Kathodenstrahlzerstäubungsanlage zur Aufbringung der $\mathrm{MoS}_{2}$ TiW Beschichtungen.

sented. For investigations the X38CrMoV5-1 steel samples from LaBoMaP-Centre Arts et Métiers de Cluny-France are used. The chemical composition (in wt\%) of the investigated X38CrMoV5-1 steel is: $0.42 \% \mathrm{C}, 0.5 \% \mathrm{Mn}, 1.2 \% \mathrm{Si}, 5.5 \% \mathrm{Cr}, 1.4 \% \mathrm{Mo}, 0.3 \% \mathrm{~V}$, Fe balance. A series of samples of $30 \mathrm{~mm}$ diameter and $2 \mathrm{~mm}$ thickness is made. The main requirement of the sample preparation process for the deposition of the $\mathrm{MoS}_{2} \mathrm{TiW}$ protective coatings is to obtain the solid surface layer with low roughness and devoid of all impurities. To this end the technological process of preparation of the samples is elaborated by using a precision grinder-polisher machine.

\section{Preparation of X38CrMoV5-1 steel samples for investigations}

The polishing process of samples made of X38CrMoV5-1 steel was carried out using a Phoenix Beta 2 (Buehler-Germany) dual platen grinder-polisher machine equipped with a Vector power head and applying Buehler abrasive materials and lubricants. The process stages of the realized operations contained:

- two-stage grinding of samples using BuehlerMet silicon carbide (SiC) abrasive paper P600 (grits size $\varnothing 26 \mu \mathrm{m}$ ) and P1200 (grits size ø $15 \mu \mathrm{m}$ );

- lapping of samples using medium hard woven silk cloth VerduTex and monocrystalline diamond suspension MetaDi (grains size $\varnothing 3 \mu \mathrm{m}$ );

- polishing of samples using soft synthetic pad ChemoMet and aluminium oxide $\left(\mathrm{Al}_{2} \mathrm{O}_{3}\right)$ final polishing suspension MasterPrep (grains size $\varnothing 0.05 \mu \mathrm{m}$ ).

The elaborated technological process ensures suitable preparation of the steel samples in the range of required roughness parameters. It also ensures proper purity of the samples. The sur- face of polished samples had silver glossy colour and invisible tool marks.

\section{Experimental apparatus and procedure}

For the deposition of $\mathrm{MoS}_{2} \mathrm{TiW}$ coatings on X38CrMoV5-1 circular steel samples, a modified hybrid PVD Cathodic Arc Evaporation (PVD CAE) system was used. The process of manufacturing of these coatings was realized in the Institute of Materials Science at the Technical University of Lodz by using multisource, hybrid factory-scale equipment of type URM 079. This equipment allows for deposition of coatings by the physical method [35]. It has two independent continuous arc power supplies with magnetic filtration of microdrop for production of metallic plasma (maximum discharge current $180 \mathrm{~V}$ ), two pulsating carbon plasma power supplies (average pulse power $1 \mathrm{~kW}$ ) and magnetron source (power $10 \mathrm{~kW}$ ) with flat circular target of $100 \mathrm{~mm}$ of dimension. This equipment allows for plasma cleaning of the surface by four independent ionic guns (4 kW/100 mA) in argon atmosphere. In the high voltage range, the polarization voltage of the substrate is controlled from $800-2500 \mathrm{~V}$. In the low voltage range, it is controlled from $0-200 \mathrm{~V}$. Nominal vacuum is below $1.0 \times 10^{-4} \mathrm{~Pa}$. The scheme of the vacuum chamber of PVD stand and its equipment are presented in Fig. 1.

\section{Microstructure of X38CrMoV5-1 steel samples with $\mathrm{MoS}_{2}$ TiW coatings}

For comparison of the microstructure of uncoated X38CrMoV5-1 steel samples with the microstructure of steel samples with $\mathrm{MoS}_{2}$ TiW coatings the optical profiler WYKO NT 1100 (Veeco 

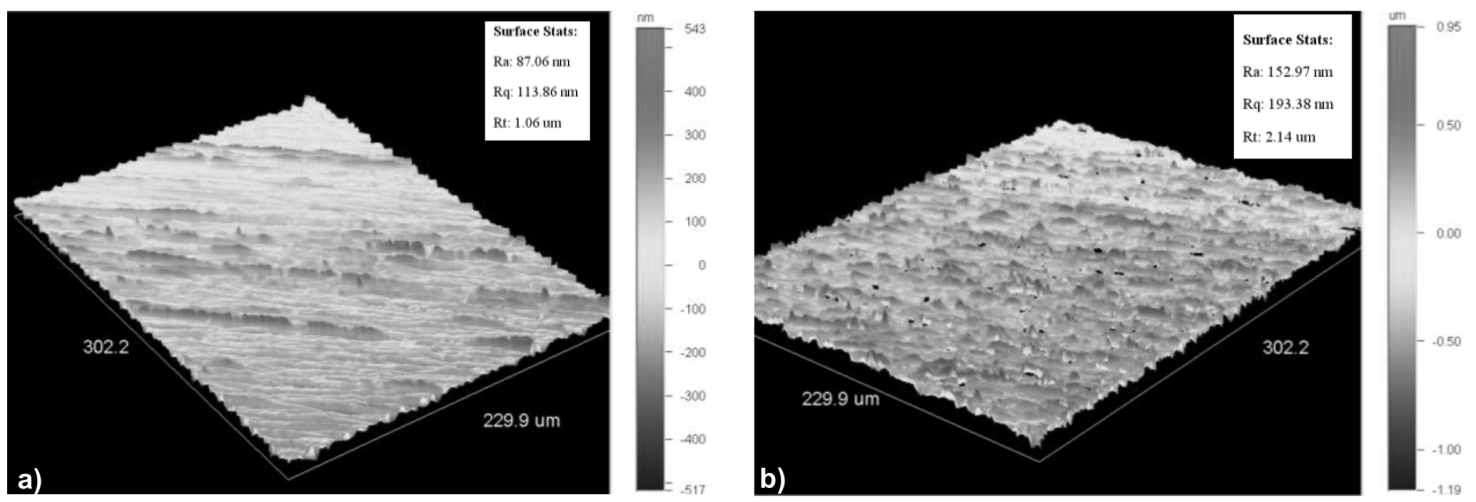

Figure 2. Microstructure images of $X 38 \mathrm{CrMoV} 5-1$ steel samples: a) uncoated after polishing, b) with $\mathrm{MoS}_{2} \mathrm{TiW}$ coatings.

Bild 2. Mikrostrukturaufnahmen der X38CrMoV5-1 Stahlproben: a) polierte, unbeschichtete Probe, b) mit MoS $\mathrm{T}_{2} \mathrm{TiW}$ Beschichtung.
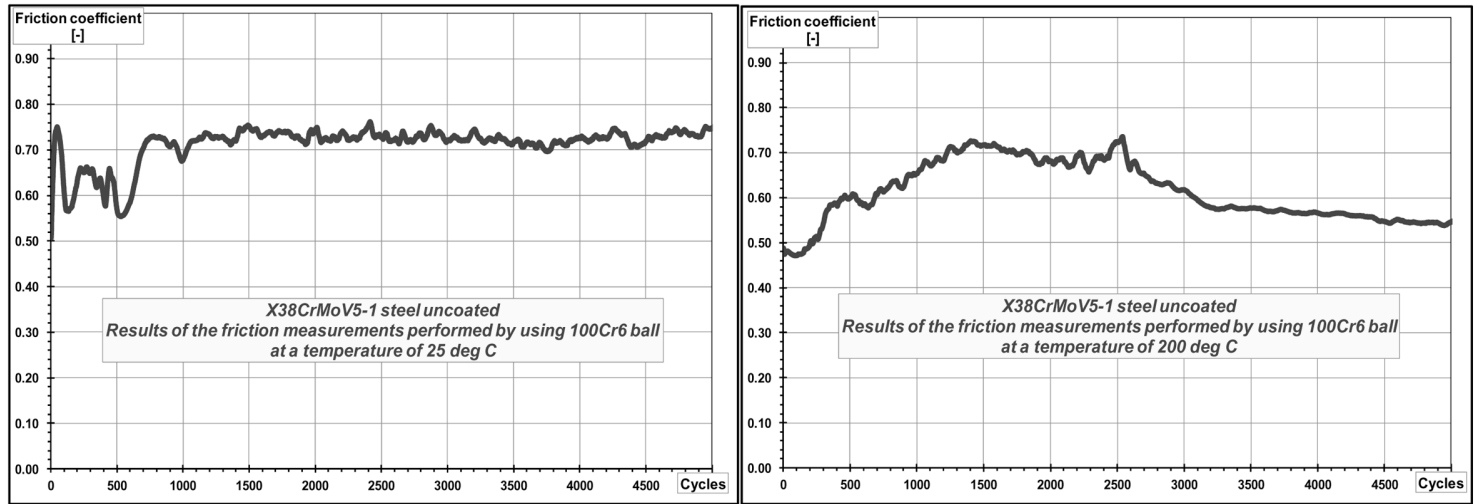

Figure 3. Friction measurements of uncoated $\mathrm{X} 38 \mathrm{CrMoV} 5-1$ steel conducted at a temperature of $25^{\circ} \mathrm{C}$ and $200^{\circ} \mathrm{C}$ by using $100 \mathrm{Cr} 6$ ball as a counter-sample.

Bild 3. Reibungsmessungen von unbeschichtetem X38CrMoV5-1 Stahl bei einer Temperatur von $25^{\circ} \mathrm{C}$ und $200^{\circ} \mathrm{C}$ mit $100 \mathrm{Cr} 6$ Kugeln als Gegenkörper.

Instruments-USA) was used. The results of investigations are presented in Fig. 2.

The results obtained here show that surface layer of X38CrMoV5-1 steel samples with $\mathrm{MoS}_{2}$ TiW coatings have regular, smooth structure but higher average roughness parameters $(\mathrm{Ra}=0.15 \mu \mathrm{m})$ than uncoated samples $(\mathrm{Ra}=0.087 \mu \mathrm{m})$.

\section{Tribological investigations of $\mathrm{MoS}_{2} \mathrm{TiW}$ coatings manufactured on X38CrMoV5-1 steel samples}

Tribological investigations of $\mathrm{MoS}_{2} \mathrm{TiW}$ coatings manufactured on X38CrMoV5-1 steel samples were done by using computercontrolled pin-on-disk tribometer (CSM Instruments-Switzerland) with a heated sample holder and with applying steel $(100 \mathrm{Cr} 6)$ and corundum $\left(\mathrm{Al}_{2} \mathrm{O}_{3}\right)$ balls as counter-samples. Tribological tests were conducted not only at ambient conditions $\left(25^{\circ} \mathrm{C}\right)$ but also at a temperature of $200^{\circ} \mathrm{C}$ because in some cases, moulds are heated in this range of temperature. Parameters of the friction coefficient test were as follows: load $-5 \mathrm{~N}$, frequency $-5 \mathrm{~Hz}$, counter-sample ball radius $-6 \mathrm{~mm}$, average velocity -10 $\mathrm{cm} / \mathrm{s}$, distance $200-800 \mathrm{~m}$. The results of friction coefficient measurements of uncoated X38CrMoV5-1 steel samples at $25^{\circ} \mathrm{C}$ and $200^{\circ} \mathrm{C}$ by using counter-samples made of different materials are presented in Figs. 3-4. Comparison of the friction measurements of X38CrMoV5-1 steel with $\mathrm{MoS}_{2} \mathrm{TiW}$ coating at $25^{\circ} \mathrm{C}$ and $200^{\circ} \mathrm{C}$ by using counter-samples made of different materials are shown in Fig. 5-6.

From the results presented above it follows that the measured friction coefficient of X38CrMoV5-1 steel samples with manufactured $\mathrm{MoS}_{2} \mathrm{TiW}$ coatings is significantly lower as compared to the steel samples without these coatings especially at high temperatures $\left(200^{\circ} \mathrm{C}\right)$. Moreover, it can be observed that the lowest values of friction coefficient both at $25^{\circ} \mathrm{C}$ and $200^{\circ} \mathrm{C}$ take place for $100 \mathrm{Cr} 6$ steel ball using as a counter-sample and even after a 800 meter test the friction coefficient does not increase, Fig. 5. It means that $\mathrm{MoS}_{2} \mathrm{TiW}$ coatings manufactured on X38CrMoV5-1 steel are characterized by very high wear resistance.

\section{Wear rate of $\mathrm{MoS}_{2}$ TiW coatings manufactured on X38CrMoV5-1 steel}

For investigations of the wear tracks of $\mathrm{MoS}_{2} \mathrm{TiW}$ coatings manufactured on X38CrMoV5-1 steel samples the optical profilometry 


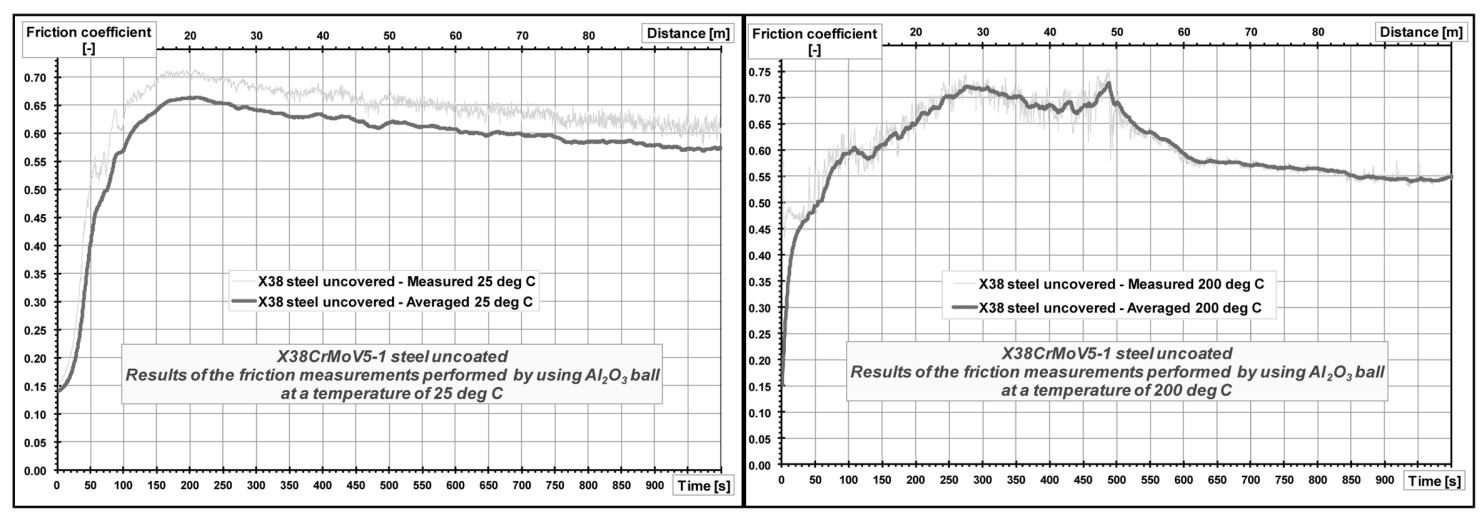

Figure 4. Friction measurements of uncoated $X 38 \mathrm{CrMoV} 5-1$ steel conducted at a temperature of $25^{\circ} \mathrm{C}$ and $200^{\circ} \mathrm{C}$ by using $\mathrm{Al}_{2} \mathrm{O}_{3}$ ball as a counter-sample.

Bild 4. Reibungsmessungen von unbeschichtetem X38CrMoV5-1 Stahl bei einer Temperatur von $25^{\circ} \mathrm{C}$ und $200^{\circ} \mathrm{C}$ mit $\mathrm{Al}_{2} \mathrm{O}_{3} \mathrm{Kugeln}$ als $\mathrm{Gegen}-$ körper.

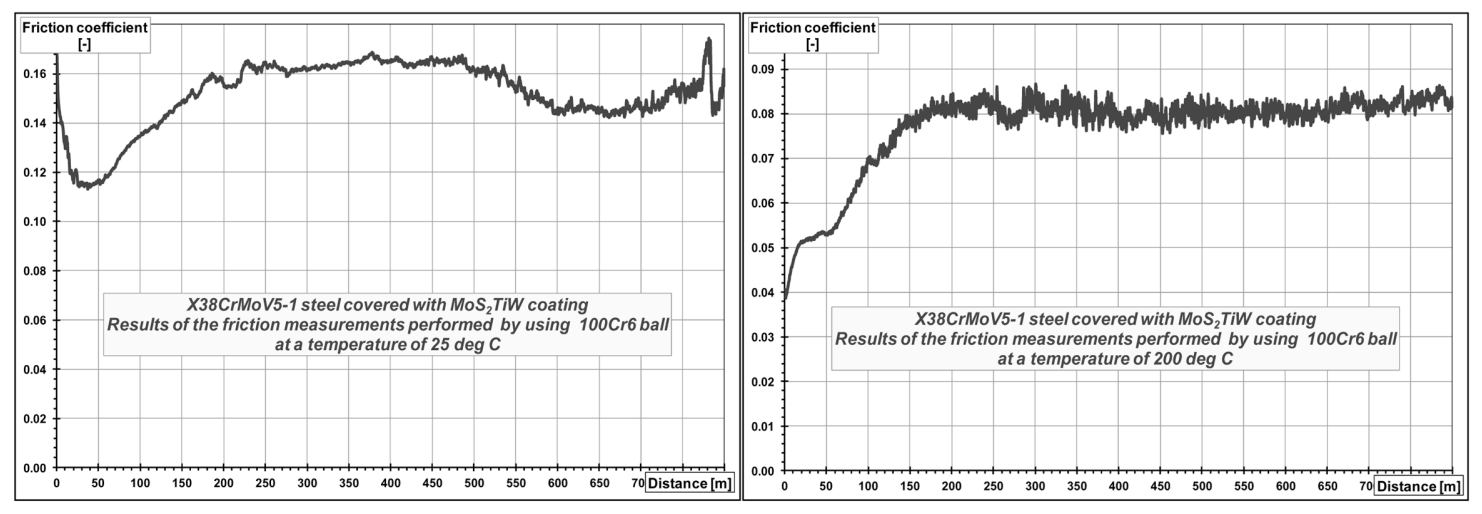

Figure 5. Comparison of friction measurements of X38CrMoV5-1 steel with $\mathrm{MoS}_{2} \mathrm{TiW}$ coating conducted at a temperature of $25^{\circ} \mathrm{C}$ and $200{ }^{\circ} \mathrm{C}$ by using $100 \mathrm{Cr} 6$ ball as a counter-sample.

Bild 5. Vergleich der Reibungsmessungen von X38CrMoV5-1 Stahl mit $\mathrm{MoS}_{2} \mathrm{TiW}$ Beschichtung bei einer Temperatur von $25^{\circ} \mathrm{C}$ und $200^{\circ} \mathrm{C}$ mit $100 \mathrm{Cr} 6$ Kugeln als Gegenkörper.

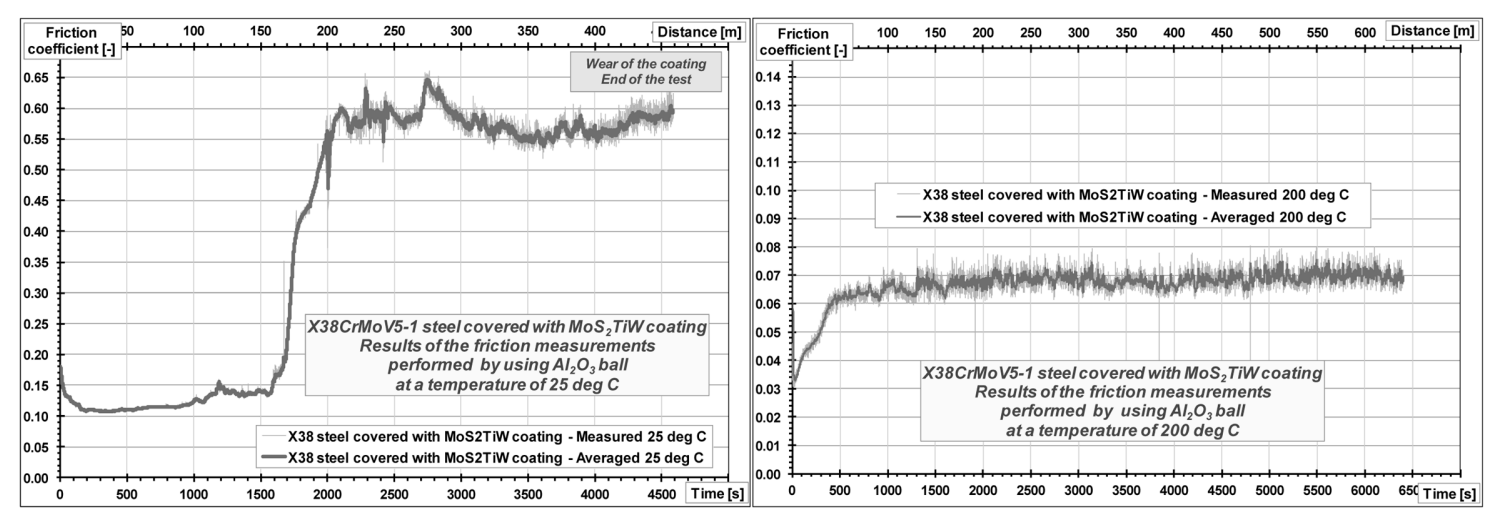

Figure 6. Comparison of friction measurements of X38CrMoV5-1 steel with $\mathrm{MoS}_{2} \mathrm{TiW}$ coating conducted at a temperature of $250 \mathrm{C}$ and $200{ }^{\circ} \mathrm{C}$ by using $\mathrm{Al}_{2} \mathrm{O}_{3}$ corundum ball as a counter-sample.

Bild 6. Vergleich der Reibungsmessungen von X38CrMoV5-1 Stahl mit $\mathrm{MoS}_{2} \mathrm{TiW}$ Beschichtung bei einer Temperatur von $25^{\circ} \mathrm{C}$ und $200{ }^{\circ} \mathrm{C}$ mit $\mathrm{Al}_{2} \mathrm{O}_{3}$ Korundkugeln als Gegenkörper.

was done by using the WYKO NT 1100 optical profiler (Veeco Instruments-USA). It allows for obtaining the profile of the track. The coatings wear tracks look like circular grooves. With the cross-sectional area of the track taken on several points it is possible to calculate the worn volume of the coatings and then to calculate the wear rate. In order to obtain a representative aver- 

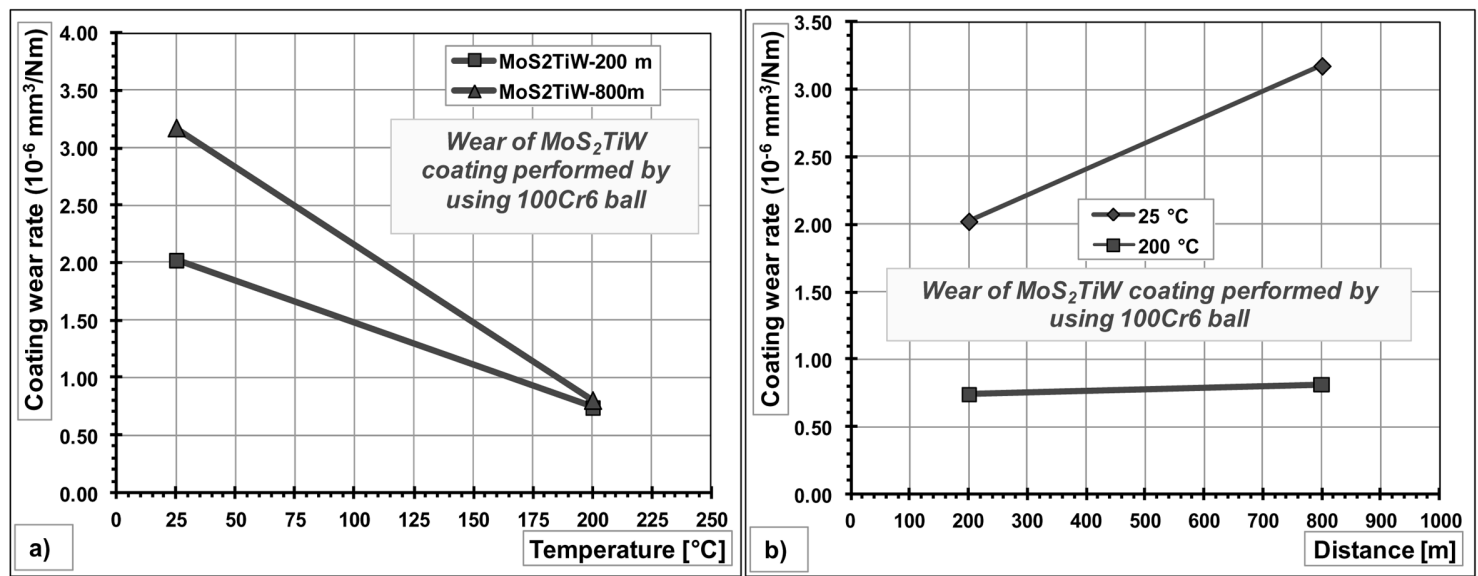

Figure 7. Wear rate of the $\mathrm{MoS}_{2}$ TiW coating manufactured on X38CrMoV5-1 steel by using $100 \mathrm{Cr} 6$ ball as a counter-sample: a) coating wear rate as a function of temperature, b) coating wear rate as a function of sliding distance.

Bild 7. Verschleißbeständigkeit der $\mathrm{MoS}_{2}$ TiW Beschichtung auf X38CrMoV5-1 Stahl mit 100Cr6 Kugeln als Gegenkörper: a) Verschleißrate als Funktion der Temperatur, b) Verschleißrate als Funktion des Gleitabstandes.
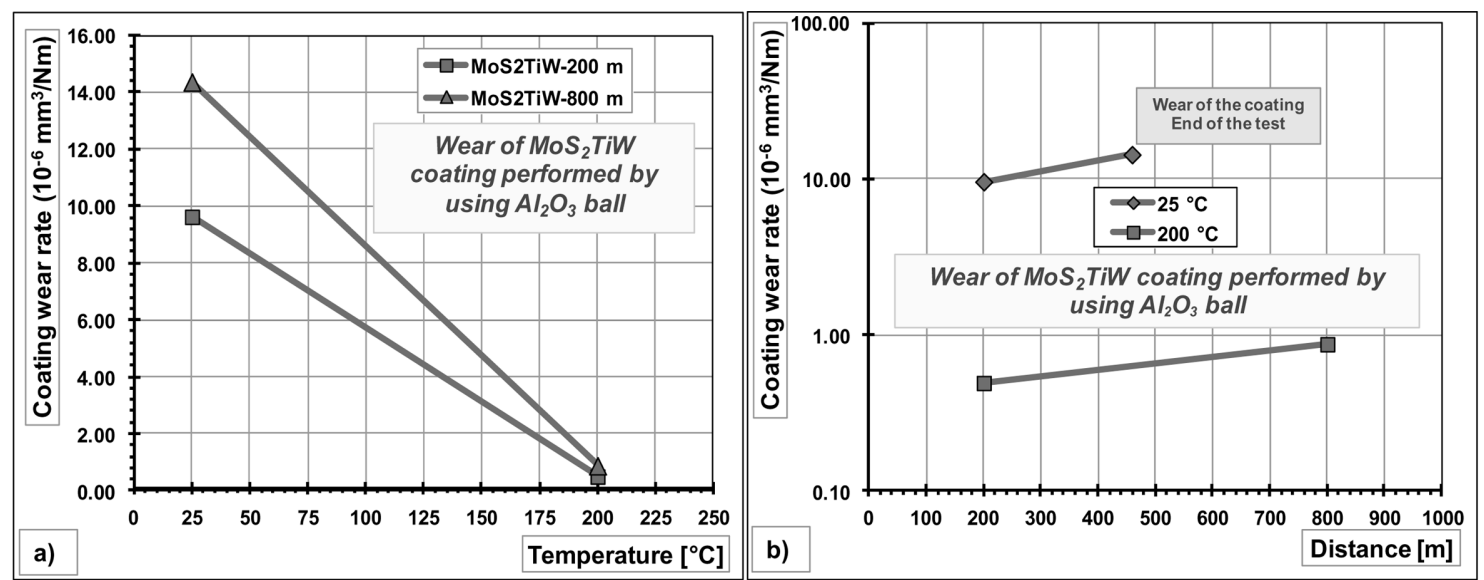

Figure 8. Wear rate of the $\mathrm{MoS}_{2}$ TiW coating manufactured on X38CrMoV5-1 steel by using $\mathrm{Al}_{2} \mathrm{O}_{3}$ ball as a counter-sample: a) coating wear rate as a function of temperature, b) coating wear rate as a function of sliding distance.

Bild 8. Verschleißbeständigkeit der $\mathrm{MoS}_{2}$ TiW Beschichtung auf X38CrMoV5-1 Stahl mit $\mathrm{Al}_{2} \mathrm{O}_{3}$ Kugeln als Gegenkörper: a) Verschleißrate als Funktion der Temperatur, b) Verschleißrate als Funktion des Gleitweges.

age, for measurements we have chosen 8 sections, one every $45^{\circ}$. One multiplies the average section by the perimeter to have the volume:

$V_{\text {track }}=2 \pi \cdot r \cdot S$

where $V_{\text {track }}$ is the worn volume $\left(\mathrm{m}^{3}\right)$, $\mathrm{r}$ is track radius $(\mathrm{mm})$ and $\mathrm{S}$ is average section $\left(\mathrm{mm}^{2}\right)$.

The wear rates of the coating and ball have been calculated according to the following equation [6]:

$K=\frac{V}{w \cdot s}$

where $\mathrm{V}$ is the worn volume $\left(\mathrm{m}^{3}\right)$, $\mathrm{w}$ is the load $(\mathrm{N})$ and $\mathrm{s}$ is the sliding distance $(\mathrm{m})$.

The obtained results are depicted in Figs. 7-8. The pictures of wear tracks of $\mathrm{MoS}_{2} \mathrm{TiW}$ coatings using optical microscopy are shown in Figs. 9-10.
The wear rate of $\mathrm{MoS}_{2} \mathrm{TiW}$ coating by using $100 \mathrm{Cr} 6$ ball as a counter-sample, at the temperature $25^{\circ} \mathrm{C}$ and after the 800 meter test, is very low $\left(3.176 \times 10^{-6} \mathrm{~mm}^{3} / \mathrm{Nm}\right)$. However, at the temperature $200^{\circ} \mathrm{C}$ and after the 800 meter test, the wear rate decreases to $8.061 \times 10^{-7} \mathrm{~mm}^{3} / \mathrm{Nm}$, Fig. 7 and Fig. 9. The wear rate of $\mathrm{MoS}_{2} \mathrm{TiW}$ coating by using $\mathrm{Al}_{2} \mathrm{O}_{3}$ ball as a counter-sample, at the temperature $25^{\circ} \mathrm{C}$ and after the 450 meter test, increases rapidly to $1.436 \times 10^{-6} \mathrm{~mm}^{3} / \mathrm{Nm}$. However, at the temperature $200^{\circ} \mathrm{C}$ and after the 800 meter test, the wear rate is very low and its averaged value is $8.744 \times 10^{-7} \mathrm{~mm}^{3} / \mathrm{Nm}$, Fig. 8 and Fig. 10 .

\section{Wear rate of the counter-sample balls made of $100 \mathrm{Cr} 6$ and $\mathrm{Al}_{2} \mathrm{O}_{3}$}

The investigations of the wear rate of the counter-samples were done based on the morphology of the balls scars by using an opti- 

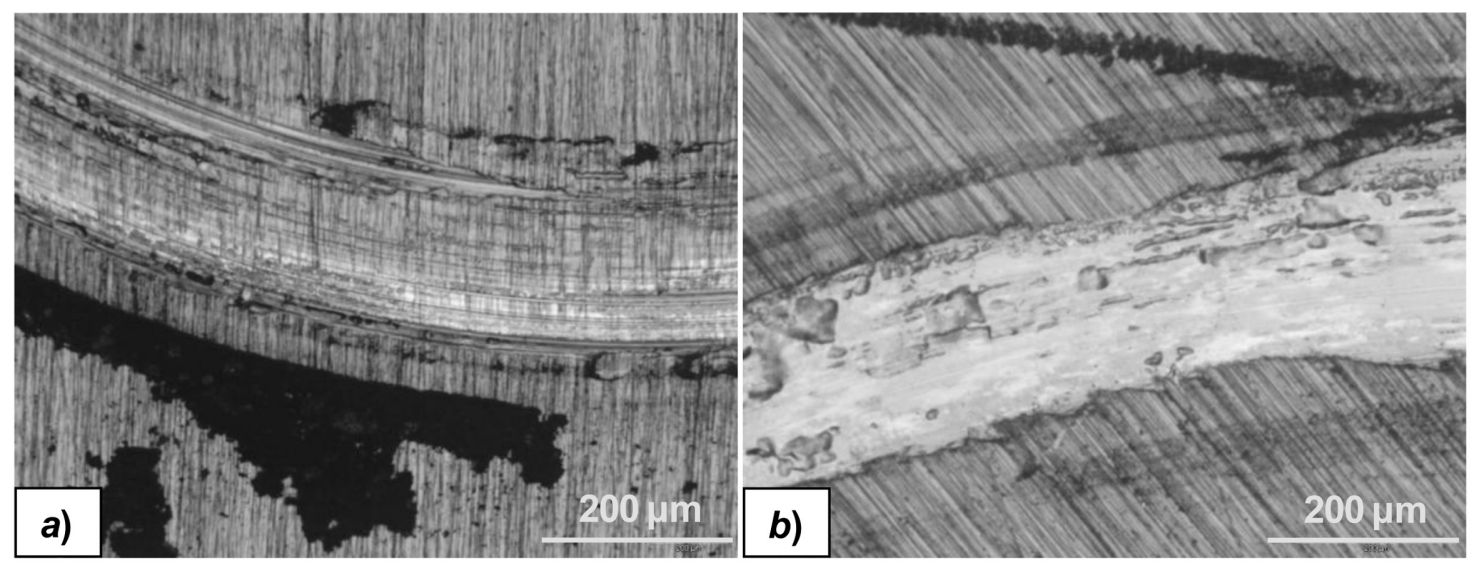

Figure 9. Wear tracks of $\mathrm{MoS}_{2} \mathrm{TiW}$ coating manufactured on $\mathrm{X} 38 \mathrm{CrMoV} 5-1$ steel sliding against $100 \mathrm{Cr} 6$ ball: a) after the 800 meter test at $25^{\circ} \mathrm{C}$, b) after the 800 meter test at $200^{\circ} \mathrm{C}$.

Bild 9. Verschleißspuren der $\mathrm{MoS}_{2} \mathrm{TiW}$ Beschichtung auf X38CrMoV5-1 Stahl bei Gleitung gegen $100 \mathrm{Cr} 6 \mathrm{Kugel}$ : a) nach $800 \mathrm{Meter}$ Test bei $25^{\circ} \mathrm{C}$, b) nach 800 Meter Test bei $200^{\circ} \mathrm{C}$.
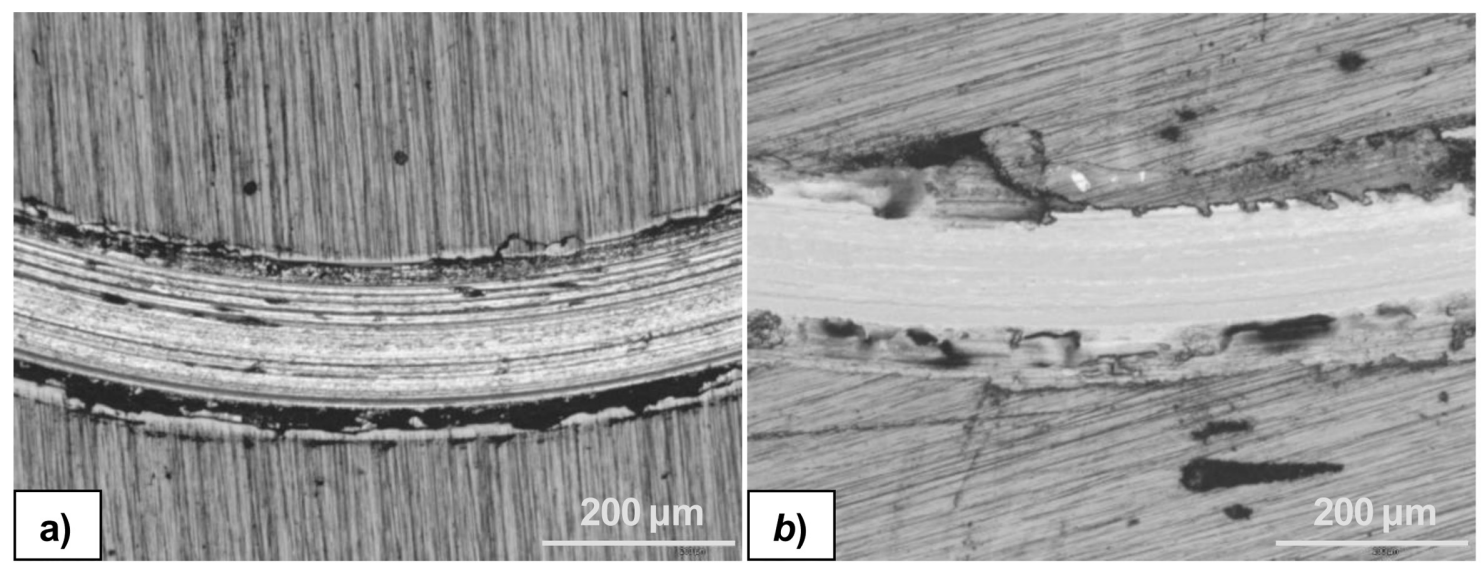

Figure 10. Wear tracks of $\mathrm{MoS}_{2} \mathrm{TiW}$ coating manufactured on $\mathrm{X} 38 \mathrm{CrMoV} 5-1$ steel sliding against $\mathrm{Al}_{2} \mathrm{O}_{3}$ ball: a) after the 450 meter test at $25^{\circ} \mathrm{C}$, b) after the 800 meter test at $200^{\circ} \mathrm{C}$.

Bild 10. Verschleißspuren der $\mathrm{MoS}_{2} \mathrm{TiW}$ Beschichtung auf X38CrMoV5-1 Stahl bei Gleitung gegen $\mathrm{Al}_{2} \mathrm{O}_{3}$ Kugel: a) nach 450 Meter Test bei $25^{\circ} \mathrm{C}$, b) nach 800 Meter Test bei $200^{\circ} \mathrm{C}$.

cal microscope. The morphology of the balls scars gives information about the friction mode and the wear mode. The size of the scar makes it possible to calculate the ball wear rate. The worn material of the balls is similar to a spherical cap.

The worn volume of the balls is calculated according to the following equations [7]:

$h_{\text {cap }}=R_{\text {ball }}-\left(R_{\text {ball }}^{2}-r_{\text {scar }}^{2}\right)^{\frac{1}{2}}$

$V_{\text {cap }}=\frac{\left.\pi \cdot h_{\text {cap }}^{2}+3 \cdot r_{\text {scar }}^{2}\right)}{6}$ or $V_{\text {cap }}=\frac{\pi \cdot h_{\text {cap }}^{2} \cdot\left(3 \cdot R_{\text {ball }}-h_{\text {cap }}\right)}{3}$

where $V_{\text {cap }}$ is the worn volume $\left(\mathrm{m}^{3}\right), \mathrm{h}_{\text {cap }}$ is the height of the cap $(\mathrm{mm}), \mathrm{R}_{\text {ball }}$ is the radius of the ball $(\mathrm{mm})$ and $\mathrm{r}_{\text {scar }}$ is the radius of the scar $(\mathrm{mm})$.

The obtained results are depicted in Figs. 11-12. The pictures of wear tracks of $100 \mathrm{Cr} 6$ and $\mathrm{Al}_{2} \mathrm{O}_{3}$ balls by using an optical microscopy are shown in Figs. 13-14.
Wear rate of $100 \mathrm{Cr} 6$ ball used as a counter-sample in the friction test of $\mathrm{MoS}_{2} \mathrm{TiW}$ coating, at the temperature $25^{\circ} \mathrm{C}$ and after the 200 meter test, is very small $\left(9.011 \times 10^{-8} \mathrm{~mm}^{3} / \mathrm{Nm}\right)$ whereas after 800 meter test it increases to $5.379 \times 10^{-7} \mathrm{~mm}^{3}$ / $\mathrm{Nm}$. At the temperature $200^{\circ} \mathrm{C}$ the wear rate of the $100 \mathrm{Cr} 6$ ball is lower after the 800 meter test $\left(2.128 \times 10^{-8} \mathrm{~mm}^{3} / \mathrm{Nm}\right)$ than after the 200 meter test $\left(9.620 \times 10^{-8} \mathrm{~mm}^{3} / \mathrm{Nm}\right)$. The ball probably wears during the running-in, then it stops to wear when the steady-state starts, particularly when the interlayer forms, Fig. 11 and Fig. 13.

The wear rate of $\mathrm{Al}_{2} \mathrm{O}_{3}$ ball used as a counter-sample at the temperature $25^{\circ} \mathrm{C}$ is rather high after the 200 meter test $\left(1.716 \times 10^{-7}\right.$ $\mathrm{mm}^{3} / \mathrm{Nm}$ ) and it increases after the 450 meter test to a value of $1.929 \times 10^{-7} \mathrm{~mm}^{3} / \mathrm{Nm}$. At the temperature $200^{\circ} \mathrm{C}$ the wear rate of the $\mathrm{Al}_{2} \mathrm{O}_{3}$ ball is very small. After the 200 meter test it is equal to $8.021 \times 10^{-8} \mathrm{~mm}^{3} / \mathrm{Nm}$. However, after the 800 meter test its averaged value is $6.899 \times 10^{-9} \mathrm{~mm}^{3} / \mathrm{Nm}$, Fig. 12 and Fig. 14 . 


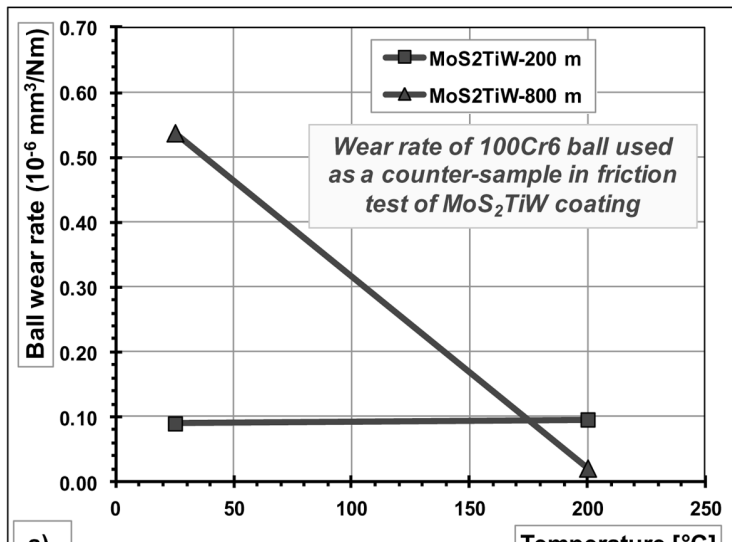

a) Temperature $\left[{ }^{\circ} \mathrm{C}\right]$

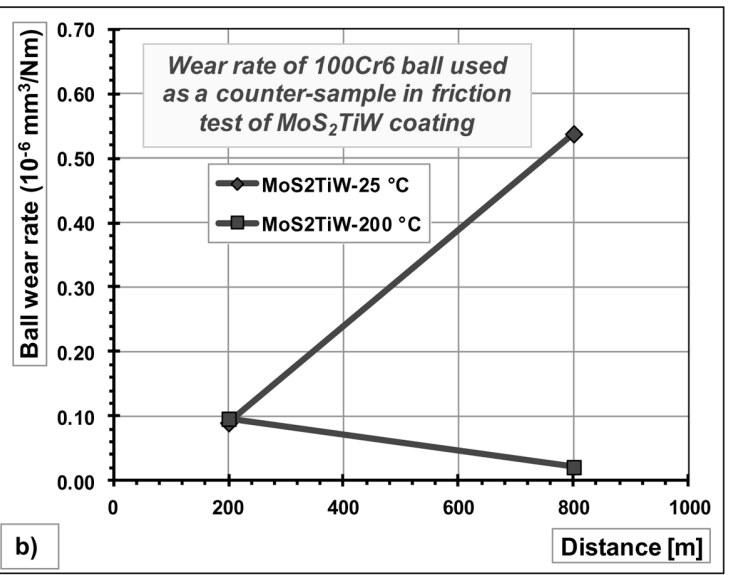

Figure 11. Wear rate of $100 \mathrm{Cr} 6$ ball used as a counter-sample: a) ball wear rate as a function of temperature, b) ball wear rate as a function of sliding distance.

Bild 11. Verschleißrate bei $100 \mathrm{Cr} 6$ Kugel als Gegenkörper: a) Verschleißrate als Funktion der Temperatur, b) Verschleißrate als Funktion des Gleitweges.
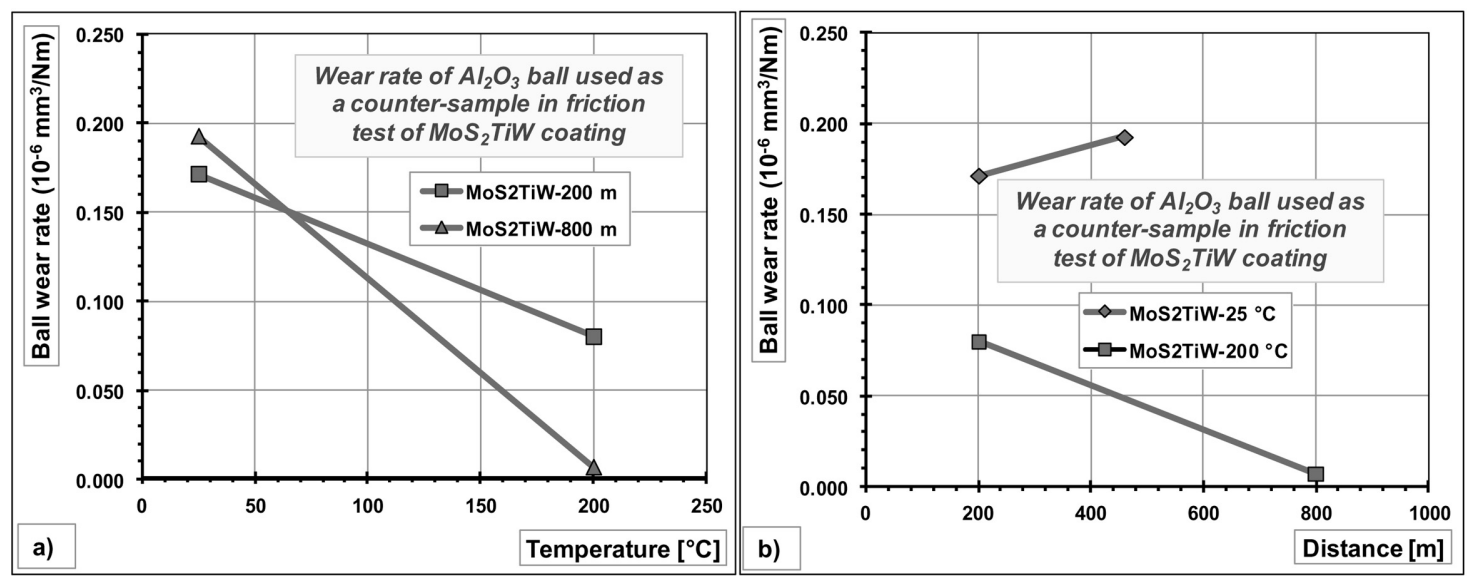

Figure 12. Wear rate of $\mathrm{Al}_{2} \mathrm{O}_{3}$ ball used as a counter-sample: a) ball wear rate as a function of temperature, b) ball wear rate as a function of sliding distance.

Bild 12. Verschleißrate bei $\mathrm{Al}_{2} \mathrm{O}_{3}$ Kugel als Gegenkörper: a) Verschleißrate als Funktion der Temperatur, b) AVerschleißrate als Funktion des Gleitweges.
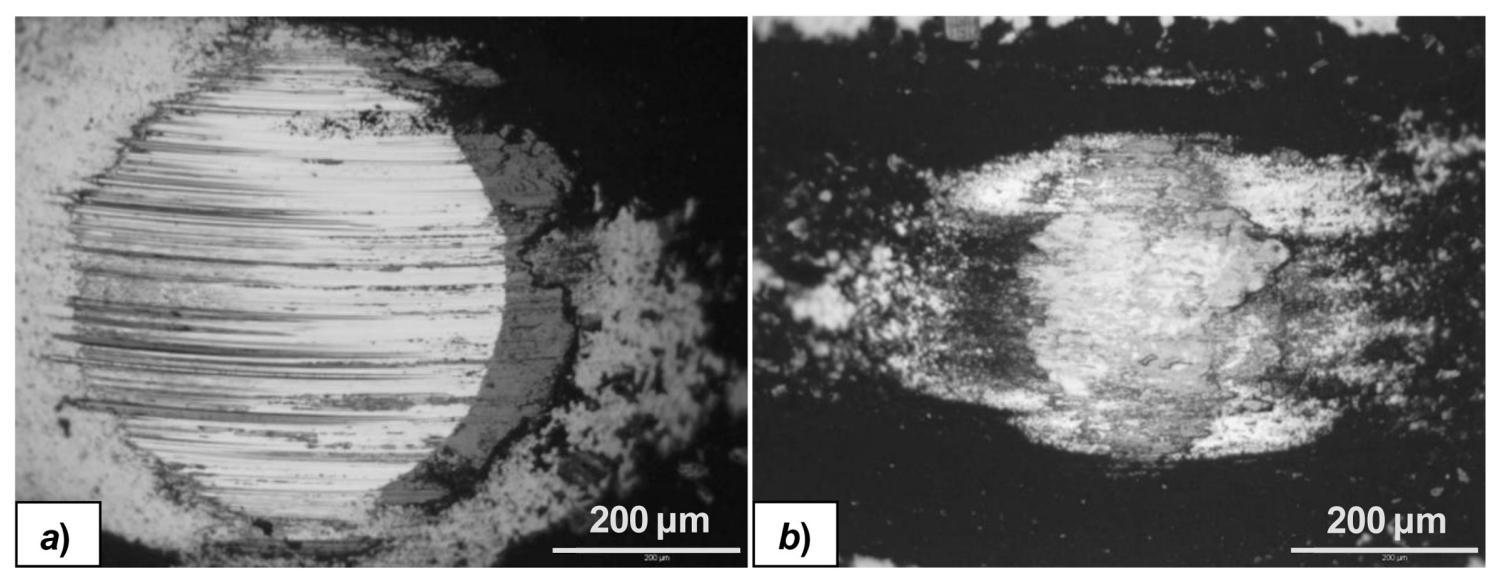

Figure 13. Wear scar of $100 \mathrm{Cr} 6$ steel ball sliding against $\mathrm{MoS}_{2}$ TiW coating manufactured on $\mathrm{X} 38 \mathrm{CrMoV} 5-1$ steel: a) after the 800 meter test at $25^{\circ} \mathrm{C}$, b) after the 800 meter test at $200^{\circ} \mathrm{C}$.

Bild 13. Verschleißzone der $100 \mathrm{Cr} 6$ Stahlkugel bei Gleitung gegen die $\mathrm{MoS}_{2}$ TiW Beschichtung auf X38CrMoV5-1 Stahl: a) nach 800 Meter Test bei $25^{\circ} \mathrm{C}$, b) nach 800 Meter Test bei $200^{\circ} \mathrm{C}$. 


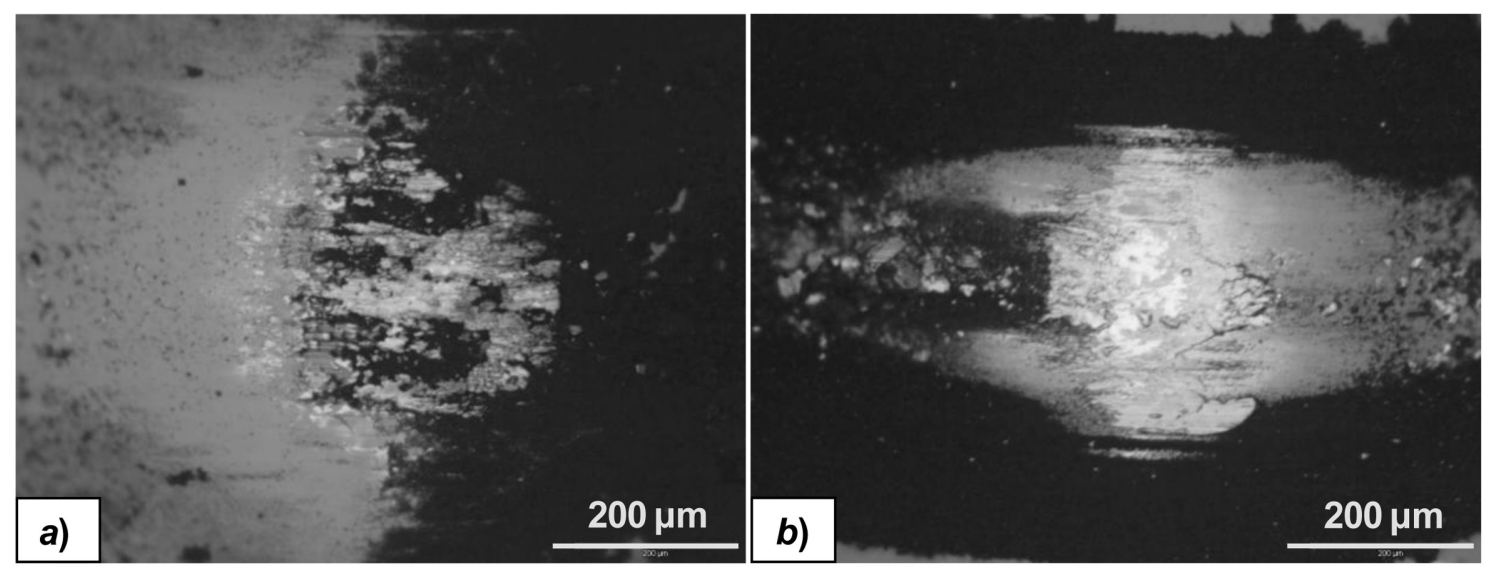

Figure 14. Wear scar of $\mathrm{Al}_{2} \mathrm{O}_{3}$ corundum ball sliding against $\mathrm{MoS}_{2} \mathrm{TiW}$ coating manufactured on X38CrMoV5-1 steel: a) after the 450 meter test at $25^{\circ} \mathrm{C}$, b) after the 800 meter test at $200^{\circ} \mathrm{C}$.

Bild 14. Verschleißzone der $\mathrm{Al}_{2} \mathrm{O}_{3}$ Korundkugel bei Gleitung gegen die $\mathrm{MoS}_{2}$ TiW Beschichtung auf X38CrMoV5-1 Stahl: a) nach 450 Meter Test bei $25^{\circ} \mathrm{C}$, b) nach 800 Meter Test bei $200^{\circ} \mathrm{C}$.

\section{Final remarks and conclusions}

Investigations carried out in this paper have confirmed that the PVD CAE method enables deposition of protective $\mathrm{MoS}_{2} \mathrm{TiW}$ coatings on X38CrMoV 5-1 steel samples. Elaborated technological polishing process of X38CrMoV5-1 steel samples ensures suitable preparation their surfaces in the range of the required roughness parameters. It also ensures the proper purity of the samples. From the results it follows evidently that $\mathrm{MoS}_{2} \mathrm{TiW}$ coatings deposited on X38CrMoV5-1 steel samples considerably improve their tribological properties. It was shown that the measured friction coefficient of steel samples with PVD coatings is significantly lower than the friction coefficient of uncoated steel especially by using a $100 \mathrm{Cr} 6$ steel ball as a counter-sample. Wear tracks of $\mathrm{MoS}_{2} \mathrm{TiW}$ coating sliding against a $100 \mathrm{Cr} 6$ steel ball are very small even after the 800 meter test and the wear of the coating is not observed. It means that $\mathrm{MoS}_{2} \mathrm{TiW}$ coatings are characterized by very high wear resistance.

\section{References}

[1] M. Hernandez, et al., Surf. Coat. Tech. 2008, 202, 1935.

[2] M. Heinze, Surf. Coat. Tech. 1998, 105, 38.

[3] M. Golabczak, A. Konstantynowicz, Defect Diffus. Forum 2010, 297-301, 641.

[4] M. Golabczak, A. Konstantynowicz, J. Nano Res. 2011, 16, 29.

[5] B. Wendler, Functional Coatings by PVD or CVD Methods, Lodz Press, Poland 2011.

[6] K. Holmberg, H. Ronkainen, et al., Surf. Coat. Tech. 2007, 202, 1034.

[7] E. P. Whitenton, P. J. Blau, Wear 1988, 124, 291. 